\title{
COMPOSTING AS A METHOD OF BIODEGRADABLE WASTE MANAGEMENT
}

UDC 628.473 .3

\section{Ivana Ilić Krstić, Jasmina Radosavljević, Amelija Đorđević, Danijela Avramović, Ana Vukadinović}

University of Niš, Faculty of Occupational Safety, Niš, Serbia

\begin{abstract}
This paper discusses the composting process as one of the methods of biodegradable waste management. It presents the fundamentals of the composting process, an overview of raw materials for composting, the basic characteristics of composting products, as well as an example of composting within the public utility company "Mediana" from Niš.
\end{abstract}

Key words: biodegradable waste treatment, composting, waste management

\section{INTRODUCTORY REMARKS}

Waste is nowadays considered one of the leading environmental problems of the modern world. Due to the increasing amount of waste generated as a result of human activities, one of the specific objectives of environmental protection is proper waste management. If waste is not managed properly, the problem of waste could be a huge burden for future generations. Introducing citizens with the need for adequate waste management is necessary because citizens are the greatest generators of utility waste.

According to the criterion of formation, waste is divided into: household (municipal) waste, waste in the public area, industrial waste, construction waste, agricultural waste, sediments and sludge from waste waters, sewage, septic tanks and street drains. [1]

The municipal waste consists of varied scrap arising as a by-product in households, institutions, stores, shops. It occurs in various forms such waste (animal and vegetable sources), ash, paper, cloth, cardboard, objects made of rubber, wood, glass, leather, porcelain, furniture, household appliances, etc.

Open fermentation and decomposition of food residues mixed with other waste not only creates an unpleasant smell that is spread by wind in the environment, but also provides ideal conditions for the rapid spread of various infectious and pathogenic microorganisms

Received April 24, 2018 / Accepted November 8, 2018

Corresponding author: Ivana Ilić Krstić

University of Niš, Faculty of Occupational Safety in Niš, Čarnojevića 10a, 18000 Niš, Serbia

E-mail: ivana.ilic@znrfak.ni.ac.rs 
and viruses. At the same time, atmospheric water passes uncontrollably through the waste dissolving a variety of harmless as well as harmful ingredients, spreading them to the wider environment.

This represents a latent risk of water contamination that cannot be underestimated. The modern treatments of solid waste include: waste reduction, reuse, recycling, composting, energy production, incineration and disposal. [1]

Composting, as a modern way of treatment of municipal waste, is an exothermic process of biological oxidation, in the course of which the organic substrate is subjected to aerobic biodegradation under the influence of microorganisms in conditions of increased temperature and humidity. In the process of biodegradation, the organic substrate undergoes physical, chemical, and biological transformations where a stable humic final product is created. This product is valuable for agriculture- both as an organic fertilizer and as a means of improving soil structure.

The following types of waste (bio-waste) can be composted:

1) Bio-waste rich in nitrogen $(50 \%)$ : fruit and vegetable residues, peel of fruit and vegetables, coffee and tea dregs, grass cuttings, weeds and plant residues in the garden, withered flowers;

2) bio-waste rich in carbon (50\%): leaves, chopped brushwood, straw and hay, fruit and grapes pruning residues, sawdust, needles of conifers. [1]

\subsection{The method of composting biodegradable waste}

One of the ways to use organic and biodegradable waste is composting. Composting is a controlled process in which, by the activity of microorganisms living in the soil (bacteria, fungi and etc.), biological and organic waste is converted into a neat humus that does not have an unpleasant odor and which can be used as a fertilizer.

According to the National Waste Management Strategy for 2010-2019 (Official Gazette of RS no 29/10) composting is defined as fast, but partial decomposition of moist, solid organic matter, food waste, garden waste, paper and cardboard with aerobic microorganisms under controlled conditions. What is got as a final product is a useful material, similar to humus, which has no odour and can be used as means for soil conditioning or as a fertilizer. [1]

Composting of garden waste is easier than composting of municipal waste, due to difference in the composition of raw materials. Municipal waste is diverse, both by type and by its homogeneity and composition, from garden waste which is relatively uniform.

Many cities in the US have banned the disposal of organic and garden waste in landfills. Only in New Jersey there are more than 200 facilities for composting, while 5 centers for composting in Ohio collect more than 180000 tonnes of organic residues, of which 6500 $\mathrm{m}^{3}$ of compost is made.

Compost is a mature product of composting, which is a product of a controlled process of bio-oxidation of a solid heterogeneous organic substrate which also includes the thermophilic phase. The composting process is biological decomposition of organic material under controlled aerobic conditions into a stable product similar to humus. [2]

Composting is controlled aerobic, thermophilic, microbiological degradation of solid organic components such as raw or processed waste sewage sludge, manure, crop residues, food residues and their mixtures to the stabilized matter similar to humus.

This is one of the methods of accelerated elimination of waste, which is the biological treatment of waste with the production of compost, and in special conditions and biogas. 
This process is based on self-heating of garbage (waste) and therefore it is also characterized as bio-thermic process. It occurs as a result of growth and development, especially of thermophilic microorganisms under aerobic conditions. During bio-thermic process the residues are heated to the temperatures which have devastating effect on pathogenic microorganisms, helminth eggs, larvae and dolls flies, which makes the residues significantly less harmful. Under the influence of microorganisms, the waste mass is subjected to the process of decomposition and creation of new substances (including humic), which become a part of a new product- the compost. Composting technology must ensure optimal conditions that will allow the elimination of hazard in a short time and obtaining the high-quality compost. [2]

The activity of bio-thermic process is largely dependent on the humidity of waste, because the microorganisms that participate in the process are fed by organic substances only in aqueous solution. If the humidity is insufficient, or the residues are devoid of water, the bio-thermic processes become slower. If the humidity is excessive, then water fills the pores and spaces between the particles of residues, air is pressed out, which causes the occurrence of the anaerobic process due to the lack of oxygen, and the composting process stops suddenly (i.e. the processes of the anaerobic methanogenesis with the formation of methane gas or biogas start). [3]

The presence of sufficient oxygen is necessary for the basic functions of aerobic microorganisms. To start the thermal process, the sufficient amount of oxygen is the one contained in the weight of the waste prior to composting. In order for the process to be successful, it is necessary that air penetrates into all parts of the waste mass. The composting process is affected by a lot of factors, but the most important factors of degradation of organic compounds are oxygen and water.

Temperature is also a very important factor; however, it is the result of microbiological activity. The degree of temperature increase is directly related to the type and the material to be composted, as it is known that during the transformation of organic materials with a higher content of nitrogen compounds a greater amount of heat is released compared to those that contain multiple carbon-carbohydrate components. Other important factors that may limit the composting process are carbon and oxygen (their role is important since they are necessary for microbiological activity and growth) and the $\mathrm{pH}$ reaction. Phosphorus and sulfur are also important, but their role in the process of composting is less known. Microelements such as $\mathrm{Cu}, \mathrm{Ni}, \mathrm{Mo}, \mathrm{Fe}, \mathrm{Zn}$, then macro-element $\mathrm{Mg}$ and useful $\mathrm{Na}$, are essential for enzyme activity, but little is known about their role in the process of composting. The minerals listed have a role in improving the quality of the compost and the speed of fermentation, as well as partial binding of liberated ammonia, which is formed in this process (for example some phosphates, carbonates, etc.), whose loss would cause "nitric depression" in the compost mass. [15]

The self-heating of organic substances during composting is the result of microbiological respiration. The temperature increase affects the microbiological population by mesophilic and thermophilic changes of organisms, which affect the decomposition rate of organic constituents. Therefore, microbiological respiration can be used as an indicator of decomposition and stability of compost (see Figure 1). Self-heating of the compost mass has a certain dynamics, so the temperature curve can be divided into mesophilic $\left(<45^{\circ} \mathrm{C}\right)$ within which there are 4 stages: 
- the initial phase (mesophilic),

- the temperature rise phase (thermophilic phase),

- the phase of maximum (thermophilic phase),

- cooling. [4]

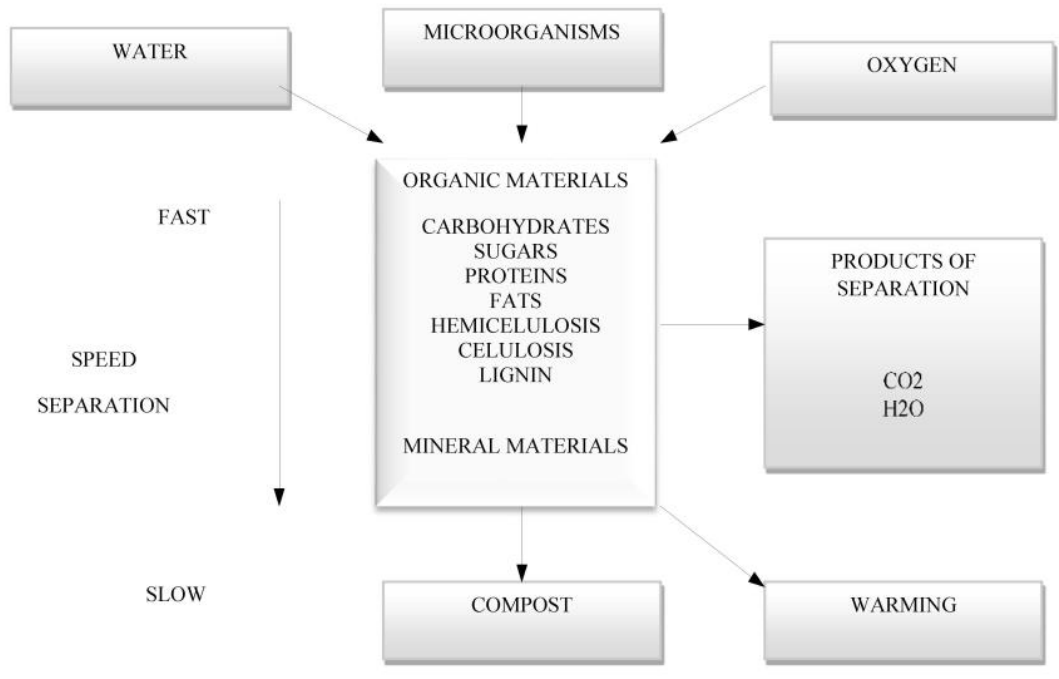

Fig. 1 Composting process [1] [15]

\subsubsection{The objectives and technologies of composting}

The main objectives of composting of various organic compounds are as follows:

1) decomposition of the organic part of waste prone to rotting process into a stable condition and production of ingredients which may be used as a soil improver or in some other useful purpose;

2) decomposition of waste into a useful product; composting can be cost effective in comparison to alternative methods of waste disposal, and it may be environmentally more acceptable than conventional methods of waste disposal;

3) disinfection of organic waste infected by pathogen so that it can be used in a secure manner;

4) biodegradation and temporary inactivation of hazardous waste by composting;

5) composting can be implemented in different ways. According to US Composting Council there are 5 different composting technologies; [3]

6) compost material is unprotected against weather influences, collected on a regular pile, the passive process without reversing or other treating of the pile, without setting the $\mathrm{CN}$ relations, the level of brightness, $\mathrm{pH}$, temperature and humidity, and the time of composting is 12-14 months;

7) compost material is unprotected against weather influences, is properly oriented in long layers like fills, an active process, with inversion of the compost mass, the convective illumination, with the initial setting of $\mathrm{CN}$ relations, the humidity control by stirring and adding water, the temperature control by mass inversion, and the time of composting is $2-12$ months; 
8) compost material is protected against atmospheric influences (overlay or otherwise), is collected on piles or is in tunnel areas, is an active process with static structure of the compost mass, with forced illumination, with the initial setting of $\mathrm{CN}$ relations, the humidity control by stirring and adding water, the temperature control by air blowing, and the time of composting is 2-6 months;

9) compost material is protected against atmospheric influences (overlay or otherwise), is set in long precinct like trenches or pools (concrete, masonry, coverage), an active process with inversion of the compost mass, the mechanical illumination, with the initial setting of $\mathrm{CN}$ relations, the humidity control by stirring and adding water, the temperature control by air blowing, and the time of composting is 2-5 months;

10)compost material is protected from atmospheric influences, is set in closed tunnels or chambers, an active process with inversion of the compost mass, with forced illumination, the initial setting of $\mathrm{CN}$ relations, the humidity control by stirring and adding water, the temperature control by air blowing, and the time of composting is 2-4 months; [4] [5]

Finding rational ways of processing the substrate and the corresponding instrumental shaping of the process will also allow the composting process to be perfected. All this leads to the artificial introduction of produced strains into the compost mass, that is, the enhancement of natural processes, followed by addition of strains which are capable of nitrogen fixation (if pre-fermented mass contains a small amount of nitrogen compounds), cellulose microorganisms, and even small amounts of mineral form of nitrogen and the like.

\subsubsection{Types of raw materials for composting}

The quality of the produced compost and composting time depend on the technology, but also on the composition of the initial compost mass. There are six basic types of materials and raw materials for composting [3]: a) the residues of food processing: compost material made after the processing of fruit, vegetables, grains and meat; b) manure and agricultural by-products formed in farrow, feedlots, incubators, farms, greenhouses and the like; c) the residues from forestry and wood industry, including the bark, sawdust and fiber residues from the production of paper; d) organic waste or waste sludge generated by treating the waste sludge in plants for purification and recycling of waste water; e) the leaves, shrubs, twigs and other plant residues such as yard and garden waste; f) the separated organic waste, comprising a composting sorted fractions of municipal waste.

\subsubsection{Compost features}

The composition of compost is reflected in the physical, biological and chemical contents thereof. The content of dry matter, ash and organic matter in analyzed samples is shown in Table 1. Since the evaporation of water is one of the consequences of degradation of organic matter, this leads to the increase of the proportion of solid matter in the compost mass. All authors note reducing of the final compost mass in relation to the initial compost mass. 
Table 1 Physical properties of analyzed compost and substrate samples

\begin{tabular}{lccc}
\hline Fat or separat & Dry substances (\%) & Ashes (\%) & Organic substances (\%) \\
\hline Fresh separat & 32.89 & 12.57 & 87.43 \\
Separat of 30 days & 38.15 & 32.25 & 64.75 \\
Separat of 90 days & 43.70 & 39.16 & 60.84 \\
Separat of 180 days & 55.71 & 43.18 & 56.82 \\
\hline
\end{tabular}

The optimum $\mathrm{pH}$ value of the compost bacteria is 6-7.5, for fungi 5.5-6.5, and actinomycetes over 7.0. [1] Also, the $\mathrm{pH}$ of the compost over 7 reduces the transfer of cadmium and other heavy metals into the food chain, as well as the potential phytotoxicity of metals. Electrical conductivity is an indicator of the content of the soluble salts in the compost. The conductivity changes depending on the quantity and types of soluble salts in solution and can indicate the potential phytotoxicity of compost. A high concentration of salt may also mean a higher concentration of plant fertilizers, but it can also have adverse effects on the plants, particularly the root of the call by stopping and slowing down the germination. The amount of $\mathrm{CO}_{2}$ which is isolated by the activity of heterothropic microorganisms in the compost is the indicator of biological activity of the material [3]. Microorganisms breathe more intensively in biologically labile compost and consume more oxygen [3]. Many authors have found in their researches that the decline in $\mathrm{pH}$ value during the composting leads to releasing more Carbon dioxide than in stable compost [6] [7]. The authors note that the $\mathrm{pH}$ reaction near neutral indicates stability of the mass. Also, a typical trend of good composting process involves decreasing of ammonium concentration and increasing of nitrate concentrations by processes of deamination, volatilization and nitrification. A consequence of the ammonia decrease and the increase of the nitrate proportion is the decrease of the $\mathrm{pH}$ value of the reaction of the compost mass.

This is why the rate of respiration is related to the stability of compost (Table 2). Compost is considered to be relatively stable when the respiration rate is less than $5 \mathrm{mg}$ $\mathrm{CO}_{2}-\mathrm{C}$ 1-G-compost $\mathrm{C}$ day-1 [2]. Respiration rate above this value indicates varying degrees of instability.

Table $2 \mathrm{pH}$ reactions of compost samples and substrate in the compost [15]

\begin{tabular}{lcc}
\hline & $\mathrm{pH}\left(\mathrm{H}_{2} \mathrm{O} ; 1: 10\right)$ & $\mathrm{EC}(1: 5 ; \mathrm{Ds} \mathrm{m}-1)$ \\
\hline Fresh separat & 8,24 & 1,28 \\
Separat of 30 days & 6,78 & 1,31 \\
Separat of 90 days & 6,66 & 1,48 \\
Separat of 180 days & 6,29 & 0,96 \\
\hline
\end{tabular}

The stability of the compost mass can be greatly affected by the amount of released $\mathrm{CO}_{2}$ [3] as shown in Table 3. According to the given parameters it may be concluded that the instability of the compost mass increases with the increase of released $\mathrm{CO}_{2}$. [15] 
Table 3 The characteristics of the compost

\begin{tabular}{|c|c|c|}
\hline mg $\mathrm{CO}_{2^{-}} \mathrm{C} / \mathrm{g}$ day-1 & Stability & Characteristics \\
\hline$<2$ & very stable & well-composted, with no odor, fragrance in the soil \\
\hline $2-5$ & stable & upper compost, minimal impact on soil dynamics \\
\hline $5-10$ & $\begin{array}{l}\text { moderately } \\
\text { stable }\end{array}$ & $\begin{array}{l}\text { uncompressed compost, slightly unpleasant smell, } \mathrm{N} \text { may } \\
\text { appear at the spot, high level of phytotoxicity, it is not } \\
\text { recommended for substrates for growing of crops }\end{array}$ \\
\hline $10-20$ & unstable & $\begin{array}{l}\text { very immature compost, unpleasant odor, phytotoxic, not } \\
\text { recommended for growing seedlings }\end{array}$ \\
\hline$>20$ & $\begin{array}{l}\text { very } \\
\text { unstable }\end{array}$ & $\begin{array}{l}\text { extremely unstable material, very unpleasant smell, high } \\
\text { phytotoxicity, is not for use }\end{array}$ \\
\hline
\end{tabular}

\subsection{The problem of municipal solid waste in the city of Niš and the composting process}

The weekly quantity of generated waste in the municipality of Niš in September for the period from $17 / 09 / 2016$ to $13 / 05 / 2016$ was more than $1300 \mathrm{t}$. In the winter, the measured mass for 7 days was $1216.8 \mathrm{t}$ of municipal waste, while in May the measured mass was 1151.52 t.[5] [6] Table 4 indicates a significant amount of waste generated in the municipality; therefore, the proper waste management is necessary along with the use of all forms and methods in the process. Taking into account the composition of waste generated in the municipality of Niš, it is necessary to develop a method of composting in the waste management process.

Table 4 Quantity of generated waste $[\mathrm{kg}]$ in the territory of the municipality of Niš

\begin{tabular}{lccc}
\hline Type of waste & $\begin{array}{c}\text { Quantity at } \\
\text { day / inhabitant }\end{array}$ & $\begin{array}{c}\text { Quantity per year / } \\
\text { inhabitant }\end{array}$ & $\begin{array}{c}\text { Quantity at the annual level } \\
\text { for the entire city }\left[\mathrm{x} 10^{3}\right]\end{array}$ \\
\hline Total waste & 0.418 & 152.57 & 45771 \\
Organic part & 0.306 & 111.69 & 33507 \\
Plastics & 0.036 & 13.14 & 3942 \\
Paper & 0.028 & 10.22 & 3066 \\
Glass & 0.016 & 5.84 & 1752 \\
Metal & 0.0026 & 0.949 & 284.7 \\
Other & 0.029 & 10.585 & 3175.5 \\
\hline
\end{tabular}

Municipal activity is the responsibility of the municipality or the utility company Mediana in Niš. The utility company deals with the collection, transport and disposal of waste. Although the company Mediana from Niš has a plant for composting organic waste, the amount of composted waste is still at a low level, if we compare it with any EU city and the amount of waste composted there. In the Table 5, we can see the percentage of different waste categories per sector of housing, accumulated in the territory of Niš. 
Table 5 Percentage of different categories of waste per sector of housing - Niš

\begin{tabular}{|c|c|c|c|c|c|c|c|c|c|}
\hline \multirow{3}{*}{$\begin{array}{l}\text { Municipality Niš } \\
\text { Waste category }\end{array}$} & \multicolumn{9}{|c|}{ Housing sector } \\
\hline & \multicolumn{3}{|c|}{ Individual } & \multicolumn{3}{|c|}{ Collective } & \multicolumn{3}{|c|}{ Village } \\
\hline & 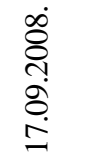 & 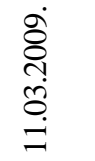 & 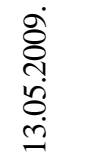 & 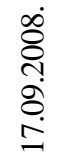 & 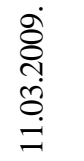 & 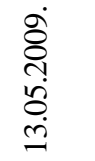 & 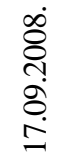 & $\begin{array}{l}\stackrel{8}{8} \\
\text { } \\
\text { ஸे } \\
\text { ô } \\
=\end{array}$ & 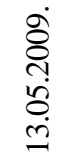 \\
\hline Garden waste & 16.45 & 7.57 & 28.29 & 5.32 & 1.95 & 3.05 & 4.40 & 11.78 & 33.11 \\
\hline Other biodegradable waste & 37.84 & 35.89 & 29.08 & 33.73 & 29.54 & 21.68 & 36.00 & 26.26 & 26.64 \\
\hline Paper & 2.80 & 8.2 & 3.57 & 2.47 & 17.44 & 13.45 & 0.94 & 6.03 & 2.47 \\
\hline Glass & 0.64 & 2.92 & 8.65 & 6.41 & 5.57 & 5.96 & 1.19 & 1.66 & 1.93 \\
\hline Cardboard & 4.18 & 3.89 & 3.41 & 3.21 & 12.3 & 8.73 & 1.88 & 7.37 & 3.90 \\
\hline Cardboard-wax & 0.46 & 0.57 & 0.50 & 0.61 & 0.5 & 1.68 & 0.31 & 0.26 & 0.52 \\
\hline Cardboard aluminum & 0.31 & 0.73 & 0.38 & 0.41 & 0.69 & 1.12 & 0.97 & 0.32 & 0.34 \\
\hline Metal-packaging and others & 1.61 & 1.46 & 0.12 & 1.55 & 1.17 & 2.66 & 0.60 & 0.72 & 0.48 \\
\hline Metal-Al Cans & 0.25 & 0.4 & 0.70 & 0.39 & 0.2 & 1.50 & 0.12 & 0.04 & 0.97 \\
\hline Plastic packaging waste & 3.62 & 2.73 & 1.91 & 3.28 & 3.17 & 2.87 & 5.91 & 1.91 & 2.05 \\
\hline Plastic bags & 6.27 & 12.23 & 3.07 & 11.56 & 12.04 & 8.93 & 10.64 & 9.3 & 3.46 \\
\hline Hard plastic & 2.69 & 3.98 & 5.04 & 6.57 & 7.12 & 9.19 & 2.73 & 3.73 & 3.52 \\
\hline Textiles & 3.73 & 7.19 & 2.35 & 15.02 & 0.59 & 2.44 & 6.80 & 7.74 & 8.36 \\
\hline Leather & 0 & 0.33 & 0.58 & 0 & 0.15 & 0.89 & 0.74 & 0.07 & 0.84 \\
\hline Diapers & 1.61 & 5 & 3.69 & 3.67 & 2.04 & 6.55 & 12.49 & 3.8 & 1.15 \\
\hline Fine elements & 17.54 & 6.91 & 8.63 & 5.80 & 5.53 & 9.31 & 14.28 & 19.01 & 10.27 \\
\hline
\end{tabular}

The utility company Mediana in Niš collects biodegradable waste in the city of Niš during the year. It also performs composting of biodegradable waste collected from the public park areas. The amount of the collected biodegradable waste annually amounts to about $3341 \mathrm{t}$ (2023.5 $\mathrm{t}$ of branches, $463 \mathrm{t}$ of leaves, $1154.5 \mathrm{t}$ of grass). The collected waste is stored in an area of about $12000 \mathrm{~m}^{2}$. Morphological composition of waste in Niš indicates that the average volume of biodegradable waste in municipal waste in Niš is $40 \%$, while this percentage increases considerably in the rural area. On the basis of collected waste it can be concluded that there is the potential of the use of bio-waste for obtaining products such as pellets and compost. The objectives of the composting process in the utility company Mediana Niš are:

1) wet waste composting in the composting plant and the possibility of using compost in agriculture, energetics and recultivation of degraded areas;

2) developing a system for composting wet waste and composting of the organic fraction of waste.

The materials used are: residues of wood, fruit, vegetables, flowers, weed, grass clipping, all types of leaves, organic waste from households and gardens. During the composting about $30 \%$ of the substrate weight is decomposed to $\mathrm{H}_{2} \mathrm{O}$ and $\mathrm{CO}_{2}$, and $70 \%$ is fermented into compost. [9] [10] 


\section{COMPOSTING PLANTS}

The most important characteristics of a composting plant is biothermic spaciousness (horizontal and rotary drum, multi-storey towers, rooms with compact or mesh walls, etc.). In order to ensure better conditions for composting, different ways of preparing waste or its treatment are used: magnetic separation, screening for separation according to size, drying and humidifying of waste. In some plants, the separation of metal parts and compost product enrichment are done at the end of the process. The plant has the equipment to implement three technological stages, providing the final cycle of waste processing: reception and pre-treatment of waste, bio-thermic processing and composting, and compost processing. When the waste reaches the plant, it is unloaded in the receiving bunker and then transferred by the conveyor belt to biodisc. Above the conveyor belt there is an electromagnetic separator that extracts magnetic metals from the waste. The horizontal rotary disc is the basis of the composting process. From it, the material is further transferred to the control cylindrical sieve. Large pieces pass through the magnetic separator and enter the bulky material waste to be stored and processes separately. Small part is crushed. The crushed material is deposited in the warehouse for finished production.

Compost can be used in agriculture only if all sanitary rules have been complied and if control of compost has been made in terms of the existence of pathogens and harmful chemicals. The value of compost is reflected in the existence of microorganisms and substances that can be detrimental to human health during their contact with the soil, through the crop plants used in human and animal diet, as well as through water, air and insects. Compost from waste contains heavy metals and rare elements, which questions the usefulness of compost as manure on agricultural land. On the other hand, some micro-elements, which are contained in the compost, are physiologically essential for the development of plants (copper, zinc, manganese, chromium, boron). Heavy metals, such as mercury, cadmium and lead from compost could contaminate the soil.

\section{CONCLUSIONS}

Using waste for composting instead of throwing them largely depends on the level of socio-economic development, public awareness and environmental policy. In our country, apart from smaller amounts of conventional vegetable compost used as an organic fertilizer, no other organic residues have been used for the process of composting. The advantages of composting are, among others, (EEA, 2002): simple, cheap and long- lasting technology; on average $40-45 \%$ of the total mass of feedstock that can be further used; maximum utilization of nutrients necessary for the use in agriculture (P, K, Mg and microelements); production of humic substances, useful microorganisms and slow-dissolving nitrogen bacteria for landscape construction; it eliminates weeds and pathogens in the waste material; the ability to control the process (except in the case of composting without aeration).

The benefits of composting of biodegradable waste are:

- protection and improvement of the environment (a healthier environment, of better quality),

- reducing the total amount of waste on the basis of composting,

- reducing the range of burning of the organic waste,

- spreading the process of composting to waste water and other organic fractions,

- applying the compost in agricultural production, and for land reclamation. 
Due to the high content of organic matter, compost has preferable ameliorative effect on improvement of water, air, thermal and biological regime. Due to increased mineral content compared to manure, it can replace mineral fertilizers. It can be used for the „revival“" of devastated areas and for the improvement of productive capacity of degraded areas, in forestry, and as a substrate in the production of various plant species.

As mentioned previously, it can be concluded that there are multiple benefits of composting biodegradable waste; therefore, it is necessary to gradually introduce composting process in each individual household.

Acknowledgement: Prepared as a part of the project Sustainability of the Identity of Serbs and National Minorities in the Border Municipalities of Eastern and Southeastern Serbia (179013), conducted at the University of Niš - Faculty of Mechanical Engineering, and supported by the Ministry of Education, Science and Technological Development of the Republic of Serbia.

\section{REFERENCES}

1. Albanell, E., Plaixats, J., Cabrero, T. (1988): Chemical changes during vermicomposting (Eisenia fetida) of sheep manure mixed with cotton industrial wastes. Biology and Fertility of Soils 6: 266-269.

2. Atiyeh, R.M., Edwards, C.A., Subler, S., Metzger, J.D. (2001): Pig manure vermicompost as a component of a horticultural bedding plant medium: effect on physicochemical properties and plant growth. Bioresource Technology 78: 11-20.

3. Ball, A. S., Shah, D., Wheatley, C.F. (2000): Assessment of the potential of a novel newspaper/horse manure-based compost. Bioresource Technology 73: 163-167.

4. Epstein, E. (1997): The science of composting. Technomic Publishing Company. Lancaster, Pennsylvania, USA. $487 \mathrm{p}$

5. Hsu, J. H., Lo, S.L. (1999): Recycling of separated pig manure: Characterization of maturityand chemical fractionation of elements during composting. Wat. Sci. Tech. 40: 121-127.

6. Hristov, S., Ristić, G., Đorđević, A. (2016): Development of Model for Household Pharmaceutical Waste Management. Working and Living Environmental Protection Vol. 13, No 2, 2016, pp. 121 - 128. UDC 628.4.045

7. Mitchell, A. (1997): Production of Eisenia fetida and vermicompost from feed-lot cattle manure. Soil Biology\&Biochemistry 29: 763-766.

8. Marković, N. (2009): Kućni otpad - od problema do rešenja. Beograd.

9. Ristić, G., Đorđević, A., Hristov, S., Umčević, P., Petković, A., Milošević, L. (2015): Methodology For Route Optimization For Solid Waste Collection And Transportation In Urban Areas. Working and Living Environmental Protection Vol. 12, No 2, pp. 187 - 197. UDC 628.475:911.37

10. Stefanović, G., Milutinović,B., Ivanović, M., Momčilović, A. (2017): Utilization of Organic Fraction of Municipal Waste In Accordance With The Principles of Circular Economy - A Case Study. Working and Living Environmental Protection Vol. 14, No 1, 2017, pp. 1 - 9. UDC 338:628.473.6

11. Thompson, W.H. (ed.) (2001): Test Methods for the Examination of Composting and Compos The United States Composting Council Research and Education Foundation. The United States Department of Agriculture.

12. Tiquia, S.M., Tam, N.F.Y. (2000): Co-composting of spent pig litter and sludge with forcedaeration. Bioresource Technology 72: 1-7.

13. Zakon o upravljanju otpadom ("Sl. glasnik RS", br. 36/2009, 88/2010 i 14/2016) 
14. Wiley, J.S. and Pierce, G.W. (1955): A preliminary study of high rate composting. Proc. Am. Soc. Civil Eng. Paper No. 846, 81: 1-28.

15. Curčić, S., Đurić, M., Milunović, S., Mandić, L. (2008): Kompostiranje kao savremeni vid tretmana čvrstog komunalnog otpada u funkciji zaštite životne sredine. Festival kvaliteta 2008. 3. Konferencija o kvalitetu života, Kragujevac, 13-15. maj 2008. Asocijacija za kvalitet i standardizaciju Srbije.

\section{KOMPOSTIRANJE KAO VID TRETMANA BIORAZGRADIVOG OTPADA}

U radu se razmatra kompostiranje kao metoda postupanja sa biorazgradivim otpadom. Prikazane su osnove metoda kompostiranja, dat je pregled polaznog materijala (sirovina) za kompostiranje, osnovne karakteristike proizvoda komposta, kao i primer kompostiranja javno komunalnog preduzeća "Mediana” iz Niša.

Ključne reči: tretman biorazgradivog otpada, kompostiranje, upravljanje otpadom 